Karamad E., PhD Student

Odessa I. I. Mechnikov National University

Odessa, Ukraine

DOI: https://doi.org/10.30525/978-9934-26-068-1-21

\title{
THE BUSINESS CASE FOR CORPORATE SOCIAL RESPONSIBILITY
}

During the past decades, Corporate Social Responsibility (CSR) has received increasing attention from management researchers and professionals. Apart from its ethical aspect, this is mainly due to its commercial benefits. As a matter of fact, according to the CEO of Olam [1, p. 14]: "The CSR movement never really took off until there was a business case for it". That is why many scholars have tried to examine, both, theoretically and empirically the relationship between CSR and profitability. In fact, it is the most developed part of CSR literature [2].

Those advocating CSR, present a number of benefits which being socially responsible delivers [3]. As according to Bowen, there is a trade-off between short term profits and CSR [4]. But the counterargument holds that the long-term benefits do offset the lost profits, hence describing it as economically worthwhile undertaking [4].

One of these business cases rests on the cost and risk reduction proposition [5]. From this perspective developing CSR can help to manage stakeholder relationship as their opposition to the organizational objectives is seen as threatening. Thus, the main motive here is to avoid risks such as customer boycotts, liability suits and so on, in addition to the costs which are derived from these.

CSR is also seen as an opportunity to create brand differentiation [6]. It has been argued that a strong brand or reputation can be used as a marketing differentiation strategy which in turn can lead to increased profitability. This can be achieved either through targeting a niche market such as ethical consumers or through cause-related marketing, which is the showcasing of the company's CSR practices [6]. Jackson [7] also argues that CSR helps to build reputational capital which in 
turn leads to premium prices charged, more investors attracted, and so on. As according to Cavett-Goodwin [8], positive and negative CSR associations can affect the consumers' product evaluation in a beneficial or detrimental way, respectively.

The above-mentioned reputational capital can also make it easier to recruit and retain talented employees, as well as, increasing their motivation [7]. This is because increasingly potential employees are interested in the organizational values consistent with their own. The resulting lower turnover and raised motivation would in turn lead to higher productivity [9].

License to operate is another argument on which a business case might be built. As according to Davis [2], a social entity must use its power in a responsible way, otherwise it will risk losing it. This is because companies are in a symbiotic relationship with their environment. This case is particularly important for those companies in highly regulated industries or those which make a marked impact on the environment and hence, need the government consent.

What is more, through behaving in a responsible way, they can also avoid public regulation and scrutiny. In fact, Rowe [10] argues that CSR is the preferred corporate strategy to deal with the popular dissatisfaction. He also adds that the evidence suggests it has thrived in those periods of time when companies have been under considerable public scrutiny.

Increased operational efficiencies can also be gained through being environmentally responsible. Costs can be decreased through minimizing waste and energy consumption [3].

These are some of the predominant propositions for a CSR business case. However, according to Davis [4], even though improved financial performance due to CSR makes sense, it is very difficult to verify it. Cavett-Goodwin [8] even though emphasizing the positive effects of CSR on companies, also admits that the lack of it can be compensated by enhancing the brand through marketing strategies. Besides, as stated in one of The Economist articles [7], engaging in CSR can actually attract more scrutiny and thus eventually prove more damaging to the reputation. Friedman also 
argued that CSR imposes cost on the firm, thus reducing its profitability. On the other hand, Frankental [11] argues that there is no evidence of financial markets rewarding responsible companies, nor penalizing those irresponsible ones. Haberberg [4] also maintains that, CSR, on the average, has no financial effect on the profitability. As for the empirical studies undertaken to establish this link between the social and financial performance, they have yielded mixed results [2].

In summary, different views on whether and how CSR is good for business have been discussed, the conclusion being there is no consensus on whether CSR leads to profitability. This calls for further research in this field, since one of the main obstacles for engaging in CSR is the unproven nature of its benefits.

\section{References:}

1. The Economist (2005) 'The importance of corporate responsibility' 15 January. The Economist Intelligence Unit. [Online]. Available at: http://graphics.eiu.com/files/ad_pdfs/eiuOracle_CorporateResponsibility_WP.pdf (accessed 5 September 2020).

2. Crane A., McWilliams A., Matten D., Moon J., Siegel D. (2009) The Oxford Handbook of Corporate Social Responsibility. New York: Oxford University Press.

3. Lee K., Carter S. (2009) Global Marketing Management' $2^{\text {nd }}$ edition. New York: Oxford University Press.

4. Haberberg A., Rieple A. (2008) Strategic Management: Theory and Application. London: Oxford University Press.

5. Kytle B., Ruggie J. (2005) Corporate Social Responsibility as Risk Management. A Model for Multinationals. Cambridge: Harvard Kennedy School.

6. Paluszek J., Ketchum C. (2005) Ethics and Brand Value: Strategic Differentiation. Santa Clara University. 6 April. Markkula Center for Applied Ethics.

7. The Economist (2004) The burdens of responsibility. A new book on corporate social responsibility fails to persuade. Building Reputational Capital. The Economist. [Online]. Available at: http://www.economist.com/node/2785791 (accessed 7 September 2020).

8. Cavett-Goodwin D. (2007) Making the Case for Corporate Social Responsibility. 4 December. Cultural Shifts [Online]. Available at: http://culturalshifts.com/archives/181/ (accessed 12 September 2020).

9. Marshal M. (2011) Globalization and Corporate Social Responsibility. FE2036 Lecture and Tutorial Slides. 13 November. London. University of East London. 
10. Rowe J. (2005) Corporate Social Responsibility as Business Strategy. Santa Cruz: University of California.

11. Frankental P. (2001) Corporate social responsibility - a PR invention?' Corporate Communications. International Journal. № 6(1). P. 18-23. MCB University Press [Online]. Available at: http://www.emerald-library.com/ft (accessed 12 September 2020). 